\title{
Semiosphere and history: Toward the origins of the semiotic approach to history
}

\author{
Mikhail Trunin \\ School of Humanities \\ Tallinn University \\ Uus-Sadama 5, M-320, Tallinn 10120, Estonia \\ e-mail: mikhail@tlu.ee
}

\begin{abstract}
This article compares the approaches to the semiotics of history of two central figures of the Tartu-Moscow School of Semiotics - Juri Lotman and Boris Uspenskij. It is argued that Lotman's approach to the semiotics of history is closely connected with the development of his theory of the semiosphere (despite Lotman's unfailing interest in history, his theoretical interpretation of the historical process was, in fact, secondary to his reflection on the semiosphere), that is, with the shift in his research from studies of literary-historical cases to typology. Meanwhile, Uspenskij, a linguist who started out as a scholar of structural language typology, moved in the opposite direction, becoming increasingly engaged in the examination of individual historical cases. Lotman's correspondence with Uspenskij serves as proof that semi-formal communication on scientific issues between the representatives of the Tartu-Moscow School was often what inspired new fundamental ideas and further development of theoretical concepts.
\end{abstract}

Keywords: Juri Lotman; Boris Uspenskij; Tartu-Moscow School of Semiotics; semiotics of history; history of science

\section{Semiotics as a meta-discipline}

The publication of Boris Uspenskij's programmatic article "Historia sub specie semioticae" in 1976 is considered the beginning of a new field in humanities - the semiotics of history. ${ }^{1}$ In fact, the article was first published two years earlier in the

1 In Bogusław Żyłko’s book about the applied semiotics of the Tartu-Moscow School, the analysis of Uspenskij's works precedes the discussion of Lotman's ideas, which are currently more popular (see Żyłko 2011: 70-94). Cf. also the statement of Taras Boyko, that "in terms of independent works and articles dedicated to the topic of history, Uspensky was probably even ahead of Lotman" (Boyko 2015: 275). 
Proceedings of the All-Union Symposium for the Study of Secondary Modelling Systems (see Uspenskij 1974; cf. Grzybek 1994: 354, fn 3; Boyko 2015: 275, fn 12). The scholars who have discussed Uspenskij's version of the semiotics of history describe it as "a model of the semiotics of history on the basis of an analogy with the linguistic act or communication in a natural language" (Hałas 2013: 72) and correctly note that "a semiotic model of historical processes was outlined in the frames of cultural semiotics, practiced by scholars associated with the Tartu school. [...] semiotics of history forms an integral part of cultural semiotics; in other words, it does not represent some radical 'historical turn' in this semiotical research program, but rather its logical extension" (Hałas 2013: 68).

In order to understand what is meant here by "logical extension", we should turn to the structure of Uspenskij's article. In its first version, the theoretical focal point through which the author considers the material under study takes up less than a fifth of the entire work (two pages out of eleven). Semiotics, of which one subspecies treats issues concerned with history, rests upon two key Saussurean dichotomies (or, in terms of the Tartu-Moscow School, "binary oppositions"): langue vs. parole and synchrony vs. diachrony.

The first of these oppositions was taken up by later researchers, who noted that "Uspenskij builds his model of the historical process according to the analogy with speech activity", where "the 'language' or the code [...] is the prevalent system of the symbolic ideas pertaining to the particular society" (Kalinin 2003: 501), or that "a historical event is a communicative event, the meaning of which for the historical process stems from a reflexive reaction - the addressee's answer" (Hałas 2013: 70). Uspenskij defends this point of view also today: in my interview with him, he describes the meaning of the word 'semiotics' similarly:

To me, semiotics is the most general linguistics. There is general linguistics, and while it is not so clear what that is exactly, it is more or less obvious that it is not an examination of one language, but of phenomena and possibilities that are realized in other languages as well. Semiotics, then, is a "general general linguistics," when even the word "language" itself is used in the broadest possible sense. ${ }^{2}$

The meaning that the scholar inserts into the phrase "language in the broadest sense of the word" (this phrase appears in both versions of Uspenskij's article, see 1974: 119;

2 See: “...такое явление природы: утверждает, что Бога нет, хотя сам как ангел”: Борис Успенский и Михаил Лотман о семиотике и советском научном быте [“....an oddity of nature: like an angel of God proclaiming 'There is no God"': Boris Uspenskij and Mihhail Lotman on semiotics and the everyday life of Soviet scholars]. Colta, "Literature" section, 6 April 2016, URL: http://www.colta.ru/articles/literature/10671 (accessed 15.07.2017). Translations from languages other than English are mine unless otherwise stated. 
1976: 286) is conditioned by his view of culture as a system, where natural language (in its narrow linguistic sense) serves as an example of a system. These notions have been quite thoroughly researched and described (for more, see Lotman, Uspenskij 1971: 146-147; in English, Lotman, Uspensky 1978: 212-213). They can be traced back to Saussure, but only really gained popularity many years later, in the 1960 s, when the Tartu-Moscow scholars were resurrecting and revamping the ideas voiced by the Russian Formalists and Prague Structuralists in the 1920s-1930s. However, in Uspenskij's "Historia sub specie semioticae", the author does not speak of developing a universal method of historical description. Rather, he focuses on developing a theoretical foundation, which Uspenskij clearly finds more engaging. Essentially, "Historia sub specie semioticae" is a detailed case study of how and why Peter the Great came to be seen as the antichrist. On the whole, it can be perceived as an analysis of his political actions and the response they received across different sections of Russian society. ${ }^{3}$

Perhaps the most central question for the humanities today is whether academic research requires conceptual frameworks rather than hermeneutic subtlety. It is therefore not surprising that contemporary researchers working within Uspenskij's scholarly legacy concentrate in their research first and foremost on the applicability of the theories he put forward. Ilya Kalinin, for instance, points out in his comparison of Lotman's and Uspenskij's respective views on the historical process that for the latter, "grammar arises as a reflective act that puts an end to all chaotic linguistic processes. The act of the system's self-reflection turns out to be the end of its history. The grammar of history based on its retrospective view illicitly presupposes historical finality. Apocalypse in that sense is the obligatory context in which the only grammatical description of history can be accomplished" (Kalinin 2003: 505). In the 1970s, however, the Tartu-Moscow scholars were completely uninterested in this issue, as both Lotman's and Uspenskij's theoretical foci could hardly be applied universally. As can be concluded from a recent self-reflective article, Uspenskij himself shares this point of view. He writes that semiotics, in the interpretation of the TartuMoscow School, was a "meta-discipline" which unified various fields pertaining to the humanities:

Describing the source material solely sub specie semioticae had never been the point: when analysing - in semiotic terms - any piece of art, any behaviour, historical event, etc. the objective was not to demonstrate what this method had to

3 Cf. Uspenskij's characteristic self-deprecation with respect to this article in his letter to Lotman from 4 December 1972: "I want to send you my Summer School pieces, probably 2 articles: on the poetics of [Velimir] Khlebnikov and on the right and left in art. I would also like to write about Peter [the Great], that he is the antichrist, but I am afraid I do not have the time [...], and it is clear anyway" (Lotman, Uspenskij 2016: 293). 
offer, but rather to discover the underlying system of signs used in the subjects we were studying. In other words, a scholar researching, say, art or history remained primarily an art historian or a historian, not a semiotician [...]. Semiotics was, in essence, an applied discipline, that is a supplementary discipline, the existence of which was justified only by its application to the material. In this approach the use of the word "semiotics" implicitly dictates the naming of the object being studied (the semiotics of something). There is a similar situation, for example, with the word "history": there can be no general history, but there can be histories of nations, peoples, things, phenomena, and so on. Accordingly, "semiotics" is understood not as a method, but as the conceptualization of the symbolic nature of a phenomenon. (Uspenskij 2016: 697-698)

The synchrony vs. diachrony opposition deserves special attention. The paragraph where it is discussed was cut from the 1976 version of the article published in the collection The Cultural Heritage of Ancient Rus and can only be found in the first one printed in Tartu:

With the passage of time, the "language" of a given community changes, which, however, does not necessarily make it impossible to discern separate synchronic cross-sections that would allow examining this "language" as an operational mechanism (compare the analogical situation with natural language). (Uspenskij 1974: 119)

This is a very important point. A clear distinction can be seen in the works of Lotman and Uspenskij from the 1970s-1980s (the period of their closest collaboration) between theoretical explanations and in-depth analyses of myriads of examples; static models and cultural dynamics; semiotics and history; synchrony and diachrony. Lotman reflects on this in his article entitled "On some principal difficulties in the structural description of a text" (1969). Building upon a famous Yurij Tynyanov quote from The Problem of Verse Language that reads "a literary form should be understood as a dynamic one", Lotman says that "[...] in describing texts [...] static models come to the fore. Identifying the reasons for this phenomenon is all the more important as there still remain those who criticize the structuralist approach for its defining feature and, in their opinion, its biggest vice, which is that it is stationary" (Lotman 1969: 478). As a solution, Lotman offers the following:

[...] a dynamic structure can be built from several static models (with a minimum of two) combined as varying links of one chain. It follows that static descriptions are not something malicious in of themselves, but, to the contrary, are an indispensible step, without which functionally mobile constructions are impossible. (Lotman 1969: 479) 
The development of Lotman's thinking is reflected in his The Dynamic Model of a Semiotic System (first published in Russian in 1974), where he argues that a dynamic process can be described as a series of static states, and diachrony, therefore, is a combination of consecutive synchronic cross-sections.

The intellectual path of Lotman himself is a vivid example of this notion: his first theories and concepts of the historical fact were put forward after the development of his theory of the semiosphere and were inextricably tied to it because they were the natural continuation of that theory. In Lotman's book Universe of the Mind, the section "Cultural memory, history and semiotics" (on this section, see Boyko 2015: 273-274) comes last, immediately following the section devoted to his theory of the semiosphere. Vyacheslav Ivanov made a point of this as well in his preface ("History and the semiosphere") to the Russian edition of the book, noting that "Lotman's entire line of thinking was the result of years of deep reflection and close study of Russian cultural history" (Ivanov 1996: VII). In "Cultural memory, history and semiotics", Lotman stresses the importance of his friend and co-author's influence and acknowledges his ideas as a source of inspiration: "Many of the ideas in this section were discussed with B. A. Uspenskij, and it is through our long-standing friendship and our many conversations that my own ideas have taken shape" (Lotman 1990: 221).

Lotman's and Uspenskij's approaches to history have already been compared by other researchers, who have come to opposite conclusions (see Kalinin 2003; cf. Pern 2012). In the present article, I will attempt to identify the problems that Lotman and Uspenskij came up against in their dealings with historical fact and narrative and that they discussed with each other over their many years of correspondence, as well as the place these problems occupy in their respective programmes of research.

\section{Against historical determinism}

To understand the difference between Lotman's late approach to history and the focus of Uspenskij's works, let us refer to the section of Universe of the Mind devoted to the problem of history and semiotics. Lotman begins by criticizing both the 19th century positivists and the Annales school historians. In the late 1920s, the founders of the Annales (who, much like the scholars of the Tartu-Moscow School, refused to call themselves a school) endeavoured to transform history into a social sciences discipline so that more complex issues could be taken up and new opportunities for problem-solving could be found among a broader scope of sources. The founders of the school were among the first to propose interdisciplinary research methods in historical studies. That said, the Annalists were practitioners rather than theorists, and they stayed away from general discussions on the philosophy of history. So what did Lotman have against the teachings of this school, which, in his own words, "brought 
a breath of fresh air into historical scholarship and enriched it with many works that are already classics" (Lotman 1990: 224)?

First of all, he could not agree with the Annales' proposed "synthesis, which is made basically with economics and sociology, takes no account of linguistics although this was just the period when linguistics was making its revolutionary changes" (Lotman 1990: 224-225). Secondly, and this is more important to Lotman, "Lying behind the methodology of this school we glimpse that age-old scientific conviction that science comes to an end at the point where determinacy ends" (Lotman 1990: 228). Here Lotman makes a polemical analogy to Marc Bloch:

History is an asymmetrical, irreversible process. To use Marc Bloch's image, history is a strange film because if we play it backwards we will not get back to the first shot. (Lotman 1990: 230)

Lotman countered arguments for linear determinism with Ilya Prigogine's ideas about self-organizing systems, according to which certain processes cease to follow linear patterns when an explosion occurs and their future course cannot be deduced from their initial conditions. The essence of the concept, while still fervently discussed, is not, however, applicable to history, and therefore immaterial for us. Vyacheslav Ivanov wrote, not without amazement:

You would think that with Lotman's very particular fascination with the history of Russian everyday life and material culture, he would have been an ally of the French Annales school of history [...]. But, unlike many of its new proponents, Lotman would never think of concentrating all his efforts on just one area of research. Among other things, he is interested in individual historical figures (and has been dedicating whole monographs to their biographical interpretation ever since his youth), as well as in the mass movements that engender explosive unpredictability. (Ivanov 1996: XII)

Suren Zolyan has pointed out that "Lotman gives two explanations of what he means by unpredictability that are not exactly identical" (Zolyan 2013:34) and has speculated that for Lotman, Prigogine's theory was

[...] concrete physical and mathematical proof that his own methodological approach to history, that he based on abundant pieces of evidence he found in culture and literature, was the right one. This is why in so many of his later works he makes references to his earlier writings. [...] Ilya Prigogine's theory was just a good opportunity to organize and apply this new semiotic device that Lotman had developed when analysing text as a meaning-generating mechanism and the semiosphere as a dynamic self-regulating system. (Zolyan 2013: 32-33) 
This makes Lotman's critique of the Annales School's rhetoric in Universe of the Mind an attempt at revising and elaborating on his own works that grew out of his theory of the semiosphere.

\section{History of science, case one: Vernadskij vs. Eisenstein}

Without a doubt, Lotman knew of Vladimir Vernadskij early on, but it appears that he did not develop an interest in Vernadskij's works until sometime in the early 1980s. Among the texts featured in the first volume of the Studies in Russian and Slavic Philology (published in 1958 and edited by Lotman) can be found Aleksej Tolstoj's address to Czechoslovak readers, which he delivered in Prague on 5 (possibly 6) October, 1935. The text was prepared for publication by Lotman's wife Zara Mints and his friend Oleg Malevich. Tolstoj began with these words:

A new scientific discipline has emerged in our country that is called 'geochemistry'. The creator of this discipline, Professor Vernadskij, formulates a law he calls the 'pressure of life': living matter seeks to exercise its functions and powers in the world, its primary aspiration being the limitless domination of all space. (Mints, Malevich 1958: 206)

It is quite telling that this mention of Vernadskij passed without comment. Vernadskij (1863-1945), a Russian-Ukrainian mineralogist and geochemist, conceived of the noosphere as of the third phase in the development of Earth, after the geosphere (inanimate matter) and the biosphere (biological life). Just as life drastically reshapes the geosphere (e.g. the atmosphere of Earth is created by living organisms), so human cognition drastically reshapes the biosphere. Another version of this concept was arrived at independently by Pierre Teilhard de Chardin (1881-1955). A French philosopher and Jesuit priest trained as a paleontologist and geologist, Teilhard de Chardin conceived of the noosphere as of the final stage in the evolution of complexity (which he equated to consciousness and Christian love) that would culminate in the "Omega Point" - the eschatological return of Christ.

The first Tartu-Moscow semiotician to "discover" Vernadskij in the 1960s was Vyacheslav Ivanov. Lotman's disciple Gabriel Superfin ${ }^{4}$ (later a dissident, and now a renowned archivist) recalls the impression left on him by a reference to Vernadskij in Ivanov's and Vladimir Toporov's book Slavic Modelling Semiotic Language Systems (1965). ${ }^{5}$ It is quite possible that Superfin was the person who pointed out Vernadskij to

\footnotetext{
4 Personal correspondence with the author (21 April 2015).

5 On this book, see Grzybek 1994: 345-346. See also a reference to Vernadskij in another article Ivanov published in Tartu during the same period - Ivanov 1967: 162, fn 11.
} 
Lotman, although this may very well be attributed to the fact that Moscow and Tartu scholars shared sources of inspiration, as Superfin himself explained. Vernadskij is also mentioned in Ivanov's Essays on the History of Semiotics in the USSR (1976), although his role in the making of Soviet semiotics is, for Ivanov, not as prominent as the role played by the film director and theorist Sergei Eisenstein.

Ivanov believed that Eisenstein's need to make generalizations, his commitment to building a universal theory of art (the pinnacle of which was the cinema), and his genius as a director were what allowed him to close in on "the problems proposed by scientists of the 20th century with completely different motivations" (Ivanov 1976: 130). At the same time, in Ivanov's book, Eisenstein is called a proponent of contemporary 'art engagé, in which artistic imagery presupposes a certain social function dictated by social (or rather governmental) demand (Ivanov 1976: 168ff). However, this was not a thing Ivanov would find reprehensible.

Lotman, to the contrary, never accepted Eisenstein's disregard for the historical fact. For him, Eisenstein was a genius in the service of an evil establishment. Eisenstein the artist edited, transformed and perverted history at the Soviet government's behest (for a closer discussion, see Trunin 2016: 99-104). In January 1968 Lotman delivered a talk at a conference held at the All-Union State Institute of Cinematography (VGIK) in honour of Eisenstein's 70th anniversary. In this speech (which, judging from the transcripts, was largely improvised ${ }^{6}$ ) Lotman allowed himself, albeit discreetly, to criticize the honoree. In all likelihood, Lotman considered his dislike of Eisenstein a matter of personal preference ${ }^{7}$ and did not think it appropriate to impose his opinion on his colleagues.

The central theme of Lotman's VGIK address and coincidentally his most serious qualm about Eisenstein, which, as the transcript shows, was the latter's destructive approach to history. Lotman claimed that Eisenstein followed the governmentimposed "general line" in his work:

6 The transcript is preserved in Lotman's archive at the Estonian Semiotic Repository Foundation (Tallinn University). There is a note in Lotman's handwriting on its front page that reads "Needs to be finished!". However, this text never became an article.

7 Boris Uspenskij remembers Lotman comparing Eisenstein the artist to a prostitute: "Is it possible to be a streetwalker and simultaneously remain an artist? Eisenstein was cynical enough to answer yes to this question. I remember our talks with Lotman about Vladimir Nabokov. Lotman proclaimed that Nabokov had written Lolita for money, but attempted to make a literary work out of a pornographic novel (Lotman demonstrated how). But Nabokov failed in this (visible seams and ill-fitting parts), which made the whole work even more repulsive, as the author himself appeared to have taken on the role of the prostitute" (personal communication with the author; 12 May 2016). 
An artist must leave room for interpretation in his work, an enigmatic element that cannot be fully interpreted, something that is still not completed. If the text is fully understood by the author, and even more so, if it is fully understood by the reader, then there is nothing to be done with it.

I believe that to a significant degree it is not just Eisenstein (a grand figure that stands out among other representatives of that era by virtue of his extraordinary talent) who strives towards creating a perfect and complete structure in his works. Meanwhile, for the structure of a text to be valuable, it must be left somewhat unfinished in its links so as to leave the audience, and perhaps the author, bewildered to some extent. There must be an opportunity left open for further development of ideas. I think the author cannot know everything [...]. He reserves the right to not know everything about his text and to continue his search for meaning. Otherwise, when every discovery has been made, there is nothing left to do with a text. (Lotman 1968: 13-14)

Even though he and his colleagues were only beginning their work on the theoretical fundamentals of their teaching, Lotman's 1968 critique of Eisenstein is essentially made from the perspective of the semiotics of culture. The idea that "closed" texts (i.e. those that do not offer room for interpretation) exist on the outer limits of culture while "open" ones lie at its core and reflect the culture's true nature, demanding a multilateral approach in their examination, was first voiced by Umberto Eco in Opera aperta (1967). Lotman's thoughts on the fundamentality of incomplete text structures and text as a generator of information are integral to his theory of the semiosphere and were summarized twenty years later in Universe of the Mind (one of Lotman's early working titles for the book was Self-Growing Logos; see also Lotman, Uspenskij 1971: 164-165; in English translation 'self-generating logos', see Lotman, Uspensky 1978: 227):

For a text, like a grain of wheat which contains within itself the programme of its future development, is not something given once and for all and never changing. The inner and as yet unfinalized determinacy of its structure provides a reservoir of dynamism when influenced by contacts with new contexts. (Lotman 1990: 18)

Eisenstein's anti-historicism is exposed in a provocative article on the semiotics of history entitled "Clio on the crossroads", in which Lotman depicts Eisenstein as an exponent of determinism: “The 'iron scenario' - Eisenstein's dream - is not a law of evolutionary systems, including history" (Lotman 1988: 4). These words must be interpreted in the frame of reference of Lotman's historical indeterminism: "History is not a ball of thread that we can endlessly unwind, but a spontaneous and autonomous avalanche of living matter" (Lotman 1988: 3). 


\section{History of science, case two: Evolution, progress and explosion}

The instances described above all serve to show Lotman's sensitivity to specific issues (particularly those pertaining to history) and his clear articulation of his thoughts on these issues. He was never quick to make sweeping generalizations.

When contrasting Lotman's and Uspenskij's concepts of history, Ilya Kalinin argues that "Uspenskij is taken as a neutral, invariant case of semiotic historiography while Lotman's case is regarded as a non-manifest drift to post-structuralism" (Kalinin 2003: 500). I believe that, to the contrary, many of Lotman's later ideas which are now considered "poststructuralist" can easily be traced back to his earlier writings. Notably, his musings on indeterminism and historical unpredictability date to as far back as the 1960s.

Lotman had a dispute with the Moscow historian Aleksandr Zimin (1920-1980) about the authenticity of Slovo o polku Igoreve [The Lay of Igor's Campaign], a core text of ancient Russian literature. Even though Lotman disagreed with Zimin's opinion that it was actually an 18th-century fake made to look like a 12th-century text, he respected the honesty and boldness of his colleague in going against the government-mandated interpretation of the Slovo. Only 101 copies of Zimin's book on this iconic text were printed by the Institute of History of the USSR Academy of Science. This was done with the sole purpose of publicly refuting Zimin's argument at a closed discussion held at the Institute on 4-6 May 1964. Nevertheless, Lotman noted that the book was clearly "written with expertise and daring" and was full of "insightful observations that contribute to science regardless of what century Slovo was written in" (for more, see Pilshchikov, Trunin 2015: 33-34).

In Volume 5 of Trudy po znakovym sistemam [Sign Systems Studies], Lotman published a polemical note that Zimin wrote in response to Lotman's own essay "On the honour-glory opposition in secular writings of the Kievan Era," and added his own, new retort to Zimin (Lotman 1971). A debate that, at first, centred on the final line of Slovo (it had been reconstructed by Roman Jakobson as "Glory to the princes, and honour to the retinue" even though there was no mention of 'honour' in the original ending [«Княземг слава, а дружинпь <честь>»]) turned, once more, into a discussion of the text's authenticity. Zimin characterized Jakobson's conjectures as "purely subjective" and said that the rest of the usages of 'honour' and 'glory' in the Slovo did not fit with the usages in other ancient Russian texts (see Zimin 1971: 466). As for Lotman's claims, Zimin said that they only strengthened his conviction that Slovo was a fake.

8 Lotman, Juri. Otzyv o knige A. A. Zimina Slovo o polku Igoreve [Review of Aleksandr Zimin's book The Lay of Igor's Campaign]. Unpublished manuscript, p. 1. Estonian Semiotic Repository Foundation (Tallinn University), f. 1. 
Lotman, who, in this case, "was not concerned with any empirical evidence" (Plyuhanova 1995: 182), not only refused to accept Zimin's reasoning but immediately countered it with a thesis that anticipated his theory of cultural explosion:

\begin{abstract}
A. A. Zimin's objections are based on a scholarly presumption that is worth discussing. Interest in the evolutionary methods of natural science proliferated in nineteenth-century philology, and the idea that having one well-documented link could always help in reconstructing the one that preceded it was quite popular. Russian literature of the 15th-16th centuries has been extensively researched and described. But if we are unable to determine which of its features were inherited from 11th-12th-century writings, we are more likely to become suspicious of what we did manage to find rather than our ability to reconstruct what was lost. The Lay of Igor's Campaign stands out against the backdrop of late medieval culture as an oddity; it does not quite "add up" in that context. But imagine that an unforeseen catastrophe had destroyed every work of literature written before 1860, as well as any mention of them, and only Eugene Onegin was spared. Would we be able to "reconstruct" Pushkin, even from literature that came from an adjacent period? (Lotman 1971: 473-474).
\end{abstract}

Evidently not, because besides the evolutionary model, "there exists another model in history, and that is culture; it develops in bright, but short-lived surges, moving forward rapidly but not accumulating much. These leaps are interspersed with standstills, 'breaks' in history during which successive links weaken. In such cases, the method of evolutionary reconstruction cannot serve as a reliable research tool" (Lotman 1971: 474).

Lotman was not fully on board with Vernadskij's concept of gradual evolutionary development. The one part in this concept that Lotman did appropriate from Vernadskij was the part about progress. Here, in Lotman's thinking, Vernadskij contrasts with Eisenstein, in whose artistic works it is not the progressive, but the regressive that holds special meaning. As Evgenij Bershtein ${ }^{9}$ remarked, Lotman relied in his later works on the concepts of 'biosphere' and 'noosphere', which he borrowed from Vernadskij, who optimistically treated evolution as progress. The biological models that Eisenstein was keen on were the complete opposite. He was obsessed with theories of biological and civilizational atavism and postulated the absolute necessity of a regressive foundation for any dialectically inclined creative person, a creator of ecstatic art.

9 Evgenij Bershtein's talk "Aquatic motifs in S. Eisenstein's Ivan the Terrible", delivered at the 8th Annual Juri Lotman Days in Tallinn University (29 May 2016). 


\section{The genesis of life and theory of the semiosphere}

A comparison of culture to the biosphere can be found in Lotman and Uspenskij's article "On the semiotic mechanism of culture": "Culture is the generator of structuredness, and in this way it creates a social sphere around man which, like the biosphere, makes life possible; that is, not organic life, but social life" (Lotman, Uspensky 1978: 213; first published in Russian, see Lotman, Uspenskij 1971: 146). However, Lotman commenced serious study of Vladimir Vernadskij's works on the 'noosphere' only later, when he started working on his seminal paper "On the semiosphere" (published in Russian in 1984). He paid far less attention to Teilhard de Chardin: Lotman refers to him only once, in the abovementioned article "Clio on the crossroads". What Lotman the historian could not accept was the idea of the end of history: he traces Teilhard's "Point $\Omega$ " back to Hegel's "Ende der Weltgeschichte". For Lotman, this concept is a harmful product of historical determinism - the main target of his critique.

Vernadskij's works on the noosphere appealed to Lotman much more than Teilhard's: he quoted them, wrote in the margins of his copies of Vernadskij's books, and discussed his reading with his friends and colleagues (both in conversations and in correspondence). Some of these responses were not included in his paper on the semiosphere and the corresponding chapter of Lotman's monograph, Universe of the Mind. In particular, one of Vernadskij's ideas "impressed" Lotman "so greatly" (his own words) that he discussed it in a letter to Boris Uspenskij on 19 March 1982. This is the concept that, in the genesis of life, communication and cognition, it is impossible to identify the moment of transition from non-life to life - and, by analogy, from nature (non-culture) to culture, from nonlinguistic communication to linguistic communication, and from non-language to language. Lotman wrote to Uspenskij:

When I was reading Vernadskij, I was struck by one of his statements. You know that I once [...] took the liberty of expressing aloud my belief that a text can [...] only exist if it is preceded by another text, and therefore any advanced culture should be preceded by another advanced culture. And I found a thought in Vernadskij a thought that is profoundly substantiated by his extensive experience as a space geologist, that life can emerge only from living [matter], that is, if it is preceded by life. This is why he considers life and dead matter (or inert matter, as he calls it) to be two primordial cosmic principles that are manifested in different forms, but always mutually separated and always in contact. As for me, I am convinced that thought cannot be evolutionarily deduced from non-thought either [...].

Interestingly enough, Vernadskij builds his argument as an empirical positivist, carefully keeping away from theological-mystical thought. ${ }^{10} \mathrm{He}$ argues thusly: science can only be based on facts, either observed or reconstructed. Nowhere

10 Lotman hints at Teilhard de Chardin here. 
in the Universe is the moment of transformation of non-life into life observed or reconstructed. Delving back millions of years, we still find some form of organic life (or traces of its existence) and non-life. All hypotheses about the origin of life are just speculation [...]. I believe that an assumption of the primordial intelligent being does not presuppose a necessity of the theological [...] point of view. ${ }^{11}$ Only the pre-existence of the semiotic sphere makes a message a message. Only the existence of the mind explains the existence of the mind. (Lotman, Uspenskij 2016: 544-545)

In the autumn of 1982 (the year in which this letter to Uspenskij was written) Lotman returned to these ideas in the first lecture of the new academic year, titled "University science - culture": ${ }^{12}$

Vernadskij described the asymmetric binarism of animate and inanimate ("inert") Nature as the two primordial principles of the existence of matter. He believed that a scientist who grounds himself in concrete experimental knowledge and does not entangle himself in the labyrinth of purely speculative reasoning does not have any data to discuss the problems of the origin of life, because, as he pointed out, no one on earth ever observed such a moment, neither in vivo nor in vitro, and all attempts to find traces of the period when there were no life forms on Earth (including the prokaryotic, lithotrophic period), do not yield any real results. (Lotman 2016: 686)

\section{Vernadskij's 1965 book The Chemical Makeup of the Earth's Biosphere and Its} Environment made a strong impression on Lotman, and a copy of it is preserved in his library. ${ }^{13}$ Lotman's marginalia correspond directly to his summary of Vernadskij's concept in his letter to Uspenskij. Lotman has marked one passage (with an "NB!" and an additional note that reads "Very important!") that deserves special attention:

[...] throughout all geological periods starting with the Precambrian, inhabiting the planet must have been at its most possible for all living matter which then existed. (Vernadskij 1965: 286)

At the same time, Lotman's 1984 article "On the semiosphere" does not mention this book at all, although it does contain five references to other works by Vernadskij. Lotman's article begins with a reflection on the Tartu-Moscow researchers' methodology, which was far from a settled question in the group. The first summer

11 Contra Teilhard again.

12 According to Roman Leibov, "Lotman never had any prepared written material to base the delivery of his lectures on" so the text discovered in the scholar's archive "could be considered an expanded abstract of his presentation" (Leibov 2017: 139, fn 3).

13 Estonian Semiotic Repository Foundation (Tallinn University), f. 5, shelf 13-4-3. 
schools that were held in Kääriku in the mid-1960s marked the beginning of this scholarly movement (later called the Tartu-Moscow School of Semiotics). These summer schools were characterized by high-level discussions, and, for Lotman, a discussion with Isaac Revzin was especially memorable:

[...] the individual act of sign exchange has come to be regarded as a model of natural language, and models of natural languages - as universal semiotic models, whereas semiotics itself has sought to be understood as the extension of linguistic methods to objects not included in traditional linguistics. This approach, originating with Saussure, was expressed with maximum clarity by the late I. I. Revzin who, during discussions at the second Summer school on secondary modelling systems in Kääriku (1966), proposed the following definition: The subject of semiotics is any object, which acts as a means of linguistic description.

Such an approach adheres to the well-known rule of scientific thinking: the movement from the simple to the complex - implicitly justifying oneself at the first opportunity. However, in this there is also the danger that heuristic expediency (the convenience of analysis) comes to be accepted as the ontological character of the object, which is assigned to it by the structure derived from the simple and clearly outlined atomistic elements, in accordance with their complexity. The complex object is thus reduced to the totality of the simple. (Lotman 2005: 206; first published in Russian, see Lotman 1984b: 5-6)

It bears repeating that when Lotman participated in the debates on structuralism back in the 1960s, he defended Revzin before such literary scholars as Pyotr Palievskij, a proponent of the intuitive study of literature, and Vadim Kozhinov, one of the best known partisans of Mikhail Bakhtin (see Seyffert 1985: 187-208, 225-230). However, in truth, even though he supported his colleague and associate to spite the antistructuralists, Lotman never agreed with Revzin's minimalist programme in the first place. In Non-Memoirs he wrote:

[...] if folklore, and literature like detective fiction - that is, the genres that are oriented towards tradition and closed language - if these are considered the natural training ground for semiotics, then the possibility of applying semiotic methods to complex open systems, like modern art, was altogether subject to doubts.

During the first Summer School, I. I. Revzin and I had a very pointed discussion about this topic [...]. Revzin, a linguist of genius [...], died too early that is, at the exact moment when he was on the brink of fundamentally new semiotic ideas. But during the first Summer School, he decidedly defended the inapplicability of semiotic methods to individual creativity, restricting them to folklore. (Lotman 2014: 77; first published in Russian, see Lotman 1995: 48)

Lotman's concept of the semiosphere was an attempt to apply semiotic methods to open systems (and, as a result, to construct complex cultural models): 
Over the last 25 years, the path of semiotic research has permitted many alternative approaches to emerge. It may now be possible to suggest that, in reality, clear and functionally mono-semantic systems do not exist in isolation. Their articulation is conditioned by heuristic necessity. Neither, taken individually, is in fact, effective. They function only by being immersed in a specific semiotic continuum, which is filled with multi-variant semiotic models situated at a range of hierarchical levels.

Such a continuum we, by analogy with the concept of "biosphere" introduced by V. I. Vernadsky, will call the 'semiosphere' [...]. The semiotic universe may be regarded as the totality of individual texts and isolated languages as they relate to each other. In this case, all structures will look as if they are constructed out of individual bricks. However, it is more useful to establish a contrasting view: all semiotic space may be regarded as a unified mechanism (if not organism). In this case, primacy does not lie in one or another sign, but in the "greater system", namely the semiosphere. The semiosphere is that same semiotic space, outside of which semiosis itself cannot exist. (Lotman 2005: 206, 208; for first publication in Russian, see Lotman 1984b: 6-7)

Lotman continues by outlining the key characteristics of the semiosphere (such as "delimitation", "semiotic unevenness": the core/periphery opposition, discreteness, heterogeneity and so on), illustrating them with a number of examples from Russian and European history and culture. However, the letter to Uspenskij and the marginalia in Vernadskij's book quoted above are helpful in tracing Lotman's idea to his immediate sources of inspiration. In his article "On the semiosphere", this idea is not expressed directly, but is intertwined with thoughts on how "the antithesis of the mythological (cyclical) and historical (linear) time" has no place in the semiosphere:

Insofar as the combination of these principles has a structural character, impacting not only on the limits of human society but also the living world, and demands the creation of general structures similar to itself, for example, in poetical works, then the question naturally arises: is the whole universe not a form of communication, falling within an ever more general semiosphere? Is it not destined for a universal reading? It is doubtful whether we were able to find an answer to this question [...]. In truth, and so conforming to the problem of interest to us, is the following principle, which V. I. Vernadsky called "the principle of P. Curie-Pasteur", may be interpreted as one of "the basic principles of the logic of science - an understanding of nature": "Dissymmetry may only be drawn out by a cause that itself already possesses dissymmetry". (Lotman 2005: 220; for first publication in Russian, see Lotman 1984b: 17-18 ${ }^{14}$ )

14 Lotman is referencing another of Vernadskij's works - The Difference between Left and Right [«Правизна и левизна», 1977]. A similar thought is voiced in the closing lines of Universe of the Mind: "The same with thought: it is both something engendered by the human brain and something surrounding us without which intellectual generation would be impossible" (Lotman 1990: 273). 
These concepts were supported by the idea of the metalinguistic function of semiotics, where the humanities and natural sciences overlapped. Lotman explains this idea in the above-mentioned lecture delivered at the University of Tartu, where he draws an analogy between the problem of the origin of life and an autocatalytic chemical reaction:

\begin{abstract}
Archaeological discoveries that reveal the existence of advanced civilizations in the layers of time, in which we did not assume the existence of history itself, remind us of the phenomenon of autocatalysis. In order to obtain the product of a chemical reaction (or to precipitate it), it is necessary to know what the product of the reaction is before the reaction starts. We can assume that, for the emergence of an advanced civilization, another advanced civilization, even if already destroyed, must be present [...]. We are confronted with the oldest and the most important question of scientific cognition - the question of the unity of the structural laws of the world. And the unifying issue for various sciences is the question of the language of description - a semiotic question. (Lotman 2016: 686-688)
\end{abstract}

Later Lotman expressed similar beliefs in a paper entitled "Culture and organism" (published in Estonian in 1984). This article is preceded by an epigraph from Vernadskij: "In the noosphere, the geological role of the human being is paramount". Lotman says:

The presumption of a structural unity of the universe makes us believe that, on different levels of organization, all kinds of matter should reveal certain isomorphic features, and, from a certain point of view, a description of everything using the means of a single meta-language is desirable. (Lotman 1984a: 215)

Lotman believes that the definition of the term "intellectual system" - "an automaton, in which information increases", - can also be applied to a "living structure". Any contact between an intellectual device and any kind of exterior information requires translation into a sign system. Signification occurs when the communicating units are mutually impenetrable to the extent that physical contacts between them are impossible or insufficient. In the evolutionary process, the self-sufficiency of a biological unit increases. The less the sense of immediate unity between the individual units, the more important the role of signs.

\title{
How Lotman and Uspenskij influenced each other
}

The historical context that brought about the aforementioned reflections on the semiosphere is equally deserving of attention. As shown above, history (resp. diachrony) and semiotics (resp. synchrony) had long existed separately in the works 
of Lotman and Uspenskij. The attempt finally to combine the two was marked by a friendly polemic which began in Lotman's correspondence with Uspenskij.

It must first be noted that Lotman took up Vernadskij precisely at the moment his scholarly trajectory took an abrupt turn. In the preceding years, Lotman had published a series of works that could be characterized as case studies - most notably, his article "Trediakovsky's Journey to the Island of Love and the function of translated literature in Russian culture of the first half of the 18th century" (Lotman 1985). He now turned to typology and broader theoretical issues. Uspenskij privately expressed several concerns about Lotman's treatment of the cultural function of Russian dandies in the era of Catherine the Great, as well as doubt that the French salon of the Marquise de Rambouillet was utopian in character. He concluded his letter with that prediction that Lotman would not agree with him on any of the points made (Lotman, Uspenskij 2016: 539-540). In his reply, Lotman wrote at length about the nature of the Russian intelligentsia, but then stopped quite abruptly and unexpectedly moved on to discussing Vernadskij, whose ideas Lotman must have found more engaging at the time (Lotman, Uspenskij 2016: 543-547).

This friendly debate remained unfinished and was continued only four and a half years later in their correspondence from 21-29 October, 1986. This time, Lotman was the critic, and the object of contention was Uspenskij's seminal article "History and semiotics (Perception of time as a semiotic problem)," which was dedicated to the semiotic status of the historical narrative and its comparison with dream discourse; it was eventually published in two different volumes of Sign Systems Studies (see Uspenskij 1988 and 1989). Lotman's main reasoning behind his critique (the better part of which Uspenskij decided to ignore) was that the material needed to be made more accessible to those historians who were not so well versed in semiotic theory (although Lotman did add a characteristic qualification: "We're not writing for idiots, of course, but if we can avoid being incomprehensible, why shouldn't we?”):

[...] when you draw your comparison between history and dreams, the common feature at the centre of that comparison is the dependence on the retelling that encodes them. They [independent readers $-M$. T.] will with $100 \%$ certainty think that you consider history unreal and in a way reminiscent of the baroque "life is a dream", and they will go on to criticize you for it. By the way, when you say that if a dream formed a coherent narrative, then it would be impossible to distinguish between dream and wakefulness. I believe you are wrong here: we take actions in real life, whereas in dreams we only see our actions' descriptions (which is why it is so easy to switch from first to third person in dreams (I get that all the time), and parts of dreams are replaced with verbal retellings). "Double takes" - where the same scene is played over again - are also only possible in dreams. These are all examples drawn from my own personal experience, not just hearsay. (Lotman, Uspenskij 2016: 595) 
Nevertheless, Uspenskij did take into account one bit of Lotman's advice: the need to distinguish terminologically between history as a series of events and a retelling of these events. In later years, almost all researchers have remarked upon this distinction, which is considered very important (see Grzybek 1994: 344; Hałas 2013: 70-71, 7475). But it was Lotman who suggested it to Uspenskij: it was so important to him that he begins one section of his letter about his friend's article with the following remark, coming back to the same point once more at the end of the letter:

The meaning of the word "history" is twofold (perhaps, not by accident): history as in historical events and history as a "story about [these] events", a historical narrative. You must differentiate between the two when you talk about semiotic, retrospective and other qualities of history [...].

Today in a dream you told me that distinguishing between history as a chain of events and history as a story about this chain of events is superficial, since history as a fact of culture begins with a story about some event, and not when the event itself actually happens, and that as time goes by, real events develop according to the laws of storytelling (this dream of mine is proof of the identity of history and dreams). I agreed with you then. But now, in the light of day, I say that it would be best to look deeper into this issue. (Lotman, Uspenskij 2016: 595, 597)

In Uspenskij's article, this distinction could be found in a footnote: "The historical text, diachronically organized on the temporal axis, must be distinguished from the synchronically organized text of events [...]. Thus, the 'language' of communication inside an event is different from the one used when describing that event" (Uspenskij 1988: 73, fn 6). In the revised version of the article published in The Selected Works, the text of the footnote cited was added to the body of the introduction: "[...] "history" can be seen as either res gestae, i.e. a set of past events, or historia rerum gestarum, a narrative of what happened, a kind of narrative text" (Uspenskij 1996: 10).

Lotman's comments on Uspenskij's article can be described as his "internal argument with himself" and "the extension of Lotman's favourite idea about the continuity of cultural traditions" (Leibov 2017: 141). I highlight the following passage:

[...] take any artistic narrative: when reading a book (especially a short story like those of O'Henry, or a detective story), we perceive the chain of events one way. But at the closing of the story, they are redistributed and allocated in a different manner that highlights only the significant parts of the narrative. It is interesting that when Beaumarchais wrote sequels to his comedies, the meaning of the original pieces that have already been successfully staged and critically acclaimed changed drastically. This is where we come to the modelling function of the text's end. It is noteworthy that chronicles that have no end and call on quite the opposite, which is the beginning, cannot really be referred to as historical, although we currently perceive them as such. (Lotman, Uspenskij 2016: 596) 
Arguments for the significance of the beginning and end of the texts can be found in one of Lotman's early structuralist works, "The modelling significance of the concepts of 'end' and 'beginning' in artistic texts" (1966), and, in a modified version, in the book Universe of the Mind (his thoughts on chronicles that he shared in a letter with Uspenskij is featured in the chapter "The semiosphere and the problem of plot", which is dedicated to the semiosphere and not history).

In his review of Uspenskij's book in German on the semiotics of history, Peter Grzybek (1994: 348) raises the following question: "How then can a meaning be attributed to a historical event? In other words: how is it possible to explain the gap between these general considerations on time perception and the basic semiotic processes involved in it [...], and cultural semiotics in general?" At the same time, he notes that "Uspenskij does not state this explicitly". It seems that it is once again Lotman who provides an answer to this question in his revision of his earlier work on the significance of the beginning and end of texts. If in 1966 he tried to build a text classification model in which the "categories of 'beginning' and 'end' were the starting point from which later both spatial and temporal constructs could be developed" (Lotman 1966: 69), almost 25 years later the problem of "the disturbance produced by narrative models on the mind of the historian" (Lotman 1990: 341) gained popularity as it became a perfect example of the influence that meta-language has on the object of study. For Lotman, the clearest example of this is Oswald Spengler:

[...] Spengler made language, the instrument of description, into the object of description - which was world history. The first action required is to cut up the historical material into pieces, and provide them with absolute beginnings and absolute ends. Historical material is of course divided into periods [...]. But the point is that even at moments of greatest change which involve large clusters of the historical strands, these changes never involve the whole of life (except perhaps when it is a matter of the physical destruction of a whole people or culture). (Lotman 1990: 243)

Thus, the 'beginning' and the 'end' are simply research tools, for in reality, neither can be determined when it comes to culture. This is where Lotman's (as well as Uspenskij's) concept of history links up seamlessly with the theory of the semiosphere and with Vernadskij's contention, which Lotman found so striking, that it is impossible to determine the original point of creation, and consequently, of culture. The chapter of Universe of the Mind entitled "Historical laws and the structure of the text" ends with the analogy (cited above from other sources) between the development of life/culture and an autocatalytic reaction in chemistry (Lotman 1990: 244).

The Tartu-Moscow scholars declared that "not only the study of the texts but of the meta-texts (instructions, rules, prescriptions, self-descriptions, etc.) of a given culture 
as well, may be extremely useful for the semiotic study of this culture, since these texts display a systematic myth the culture creates about itself" (Grzybek 1994: 353). The question of the school's own meta-language is one that continues to be relevant today. Once again, semiotics proves to be similar to history as Lotman and Uspenskij conceive of it, as it "is not only an instrument for cultural studies; it has also rendered one of its possible objects - the (meta-)texts produced by a given culture (or a cultural sub-group) become part of this culture, too" (Grzybek 1994: 353-354).

\section{(Re)turning to the historical studies}

At around the same time, in the late 1980s, two processes were taking place within the Tartu-Moscow School: discussion of the concepts being developed by individual researchers (see above), and a more global, reflective process. As self-justification was no longer an issue, the movement's pioneers were now turning away from the question of the movement's predecessors to the lasting contribution of the movement. Once again the problem of semiotics and history was on everyone's mind. The 20th volume of Sign Systems Studies (1987), which featured Uspenskij's famous article "On the problem of the genesis of the Tartu-Moscow School of Semiotics," began with a kind of forum discussion - "On the results and challenges of semiotic research" - in which Lotman and scholars like Toporov and Ivanov replied to a set of questions. Looking back over the last 25 years of research, Lotman said the following:

On the one hand, one really sensed a drive to come to grips with the evolution of existing humanistic thought [...], and on the other hand, there was a noticeable influence from the transition over the preceding decades in modern linguistics to new schools and ideas. This made semiotic research more dynamic. The upside of this rapid development was the sheer number of new ideas and new research questions; the downside was that not much fundamental research was getting done $[\ldots]$.

One of the aspects of this shift in scholarly interests, as I see it, is a movement away from general structures (languages, codes) to the issue of textuality and the analysis of individual texts, and from a strictly synchronic approach to a historical one. (Lotman 1987: 13)

Lotman here describes a problem he himself came up against more than once when he was moving from strictly historical and literary studies to those which are now generally called "structuralist". As discussed above, Lotman and Uspenskij treated semiotics as a tool specifically designed for solving a limited number of scholarly problems suggested by particular areas of research. This kind of approach entails a description of a synchronic cross-section of culture; it offers no room for evolution, i.e. 
diachrony. When addressing a particular case, Lotman and Uspenskij were well aware of the fact that their respective approaches were far from universal.

For Lotman, it was the semiosphere theory inspired by Vernadskij that became his attempt to combine synchronic and diachronic approaches. The next step was, in Lotman's own words, the return to history, as he plainly states:

Personally, I cannot draw a sharp line where, for me, a historical description ends and semiotics begins. There is neither opposition nor gap. For me, these areas are organically linked. It is important to keep this in mind because the semiotic movement began from the denial of historical studies. Abandoning the historical study was necessary in order to return to it later. (Lotman 1993: 41)

This is why it is not the least bit surprising that the 25th volume of Sign Systems Studies (1992) - the last one ever edited by Lotman - carried the subtitle "Semiotics and history". Moreover, according to Ivanov's memoirs (1996: XI), the contents of this volume were the result of the last Summer School held in Kääriku after a long break. ${ }^{15}$

The foreword features an essay on the same topic (as an aside, it certainly reads like a programme of research that was never implemented):

Semiotics has changed during the past decades. One of its accomplishments along its difficult path was its joining with history. The perception of history has become semiotic, and semiotic thinking has acquired historical features.

Traditional historical research proceeded from the presumption that history deals with the finite past. [...] History was seen as static or at least something that came to a halt when the historical work was being written. The semiotic approach wants to avoid this conventional halting of the historical process. To achieve this, the historian-semiotician's own point of view must become one of the objects of his research, as a part of the historical process in its own right. (Lotman 1992: 3-4)

Thus, the influence of Lotman and Uspenskij on each other as their semiotic approach to history was taking shape can be described using the properties of Lotman's very own semiosphere - it was reciprocal, discrete and asymmetric. Uspenskij recalls:

[...] at the time [that is, 1964, when he met Lotman. - M. T.], I was not doing any history, I was only interested in structural linguistics [...]. I was interested in that

15 The famous Summer Schools are one of the brands of the Tartu-Moscow School of Semiotics. They took place in Kääriku in 1964, 1966, 1968 and 1970. The next school was to be held in Yerevan (Armenia) in 1972, or Kääriku in 1973 but was suppressed (see Lotman, Uspenskij 2016: 273-275). In the winter of 1974, the All-Union Symposium for the Study of Secondary Modelling Systems was held in Tartu. After a long pause, the next and last Summer School of the Soviet period was held in Kääriku in 1986. 
sort of combinatorics: what is a morpheme, can it exist inside the root or not, purely structural questions. It was contact with Juri Mihailovich that made me study history. ${ }^{16}$

It is significant that the evolution of Lotman's scholarship actually went in the opposite direction: from studies of the history of literature to typology, and then from typology to the semiotics of culture and history. ${ }^{17}$

\section{References}

Boyko, Taras 2015. Describing the past: Tartu-Moscow School ideas on history, historiography, and the historian's craft. Sign Systems Studies 43(2/3): 269-280.

Grzybek, Peter 1994. Semiotics of history - historical cultural semiotics? Semiotica 98(3/4): 341-356.

Hałas, Elżbieta 2013. The past in the present. Lessons on semiotics of history from George H. Mead and Boris A. Uspensky. Symbolic Interaction 36(1): 60-77.

Ivanov, Vyacheslav 1967. Struktura stihotvoreniya Khlebnikova "Menya pronosyat na slonovyh...". Trudy po znakovym sistemam [Sign Systems Studies] 3: 156-171. [Иванов, Вяч. Вс. 1967. Структура стихотворения Хлебникова «Меня проносят на слоновых...». Труды по знаковым системам 3: 156-171.]

- 1976. Ocherki po istorii semiotiki v SSSR. Moscow: Nauka. [Очерки по истории семиотики в СССР. Москва: Наука.]

- 1996. Semiosfera i istoriya. In: Lotman, Juri M. Vnutri myslyashchih mirov: Chelovek tekst - semiosfera - istoriya. Moscow: Yazyki russkoj kul'tury, VII-XIV. [Семиосфера и история. In: Лотман, Ю. М. Внутри мыслящих миров. Человек - текст - семиосфера история. Москва: Языки русской культуры, VII-XIV.]

Kalinin, Ilia 2003. The semiotic model of a historical process: History - between grammar and rhetoric. Sign Systems Studies 31(2): 499-509.

Leibov, Roman 2017. Sõprus kui kultuurifenomen. Keel ja Kirjandus 2: 139-143.

Lotman, Juri 1966. O modeliruyushchem znachenii ponyatij 'kontsa' i 'nachala' v hudozhestvennyh tekstah. In: Lotman, Juri (ed.), Tezisy dokladov vo Vtoroj letnej shkole po vtorichnym modeliruyushchim sistemam 16-26 avgusta 1966, Tartu: University of Tartu, 69-74. [Лотман, Ю. М. 1966. О моделирующем значении понятий «конца» и «начала» в

\section{See fn 2}

17 Acknowledgments: This research was made possible by the Estonian Research Council grant PUT634 ("Estonian semiotics in cross-cultural context: New primary data and prospects for recalibration in the 21st century"). The article is partly based on the paper co-authored with Igor Pilshchikov and presented at the conference "Reintroducing the semiosphere" (8th Annual Juri Lotman Days at Tallinn University, 27 May 2016) under the title "Semiosphere, glotogenesis, Orbis Tertius: Juri Lotman's interpretations of Vladimir Vernadskij and contemporary perspectives for the theory of the semiosphere". The author is grateful to Joseph Peschio and Marek Tamm for their help, critical comments and suggestions. 
художественных текстах. In: Лотман, Ю. М. (ред.), Тезисы докладов во Второй летней школе по вторичным моделирующим системам 16-26 августа 1966, Тарту: Тартуский государственный университет, 69-74.]

- 1968. Стенограмма выступления на конференции по наследию Эйзенштейна во ВГИКе [The transcript of the talk on the conference devoted to Eisenstein's legacy at AllUnion State Institute of Cinematography]. Unpublished typescript. Estonian Semiotic Repository Foundation (Tallinn University), 16 pp.

- 1969. O nekotoryh printsipial'nyh trudnostyah v strukturnom opisanii teksta. Trudy po znakovym sistemam [Sign Systems Studies] 4: 478-482. [О некоторых принципиальных трудностях в структурном описании текста. Труды по знаковым системам 4: 478482.]

- 1971. Eshche raz o ponyatiyah 'slava' i 'chest" v tekstah Kievskogo perioda. Trudy po znakovym sistemam [Sign Systems Studies] 5: 469-474. [Еще раз о понятиях «слава» и «честь» в текстах Киевского периода. Труды по знаковым системам 5: 469-474.]

- 1984a. Kultuur ja organism. In: Tiivel, Toomas; Kull, Kalevi; Neuman, Toomas; Sutrop, Urmas (eds.), Teooria ja mudelid eluteaduses. Tartu: Tartu Riiklik Ülikool, 215-220.

- 1984b. O semiosfere. Trudy po znakovym sistemam [Sign Systems Studies] 17: 5-23. [O семиосфере. Труды по знаковым системам 17: 5-23.]

- 1985. "Ezda v ostrov l'ubvi” Trediakovskogo i funktsiya perevodnoj literatury v russkoj kul'ture pervoj poloviny XVIII v. In: Stepanov, Georgij V. (ed.), Problemy izucheniya kul'turnogo naslediya. Moscow: Nauka, 222-230. [«Езда в остров любви» Тредиаковского и функция переводной литературы в русской культуре первой половины XVIII в. In: Степанов, Г. В. (ред.), Проблемь изучения культурного наследия. Москва: Наука, 222-230.]

- 1987. Ob itogah i problemah semioticheskih issledovanij. Trudy po znakovym sistemam [Sign Systems Studies] 20: 12-16. [Об итогах и проблемах семиотических исследований. Труды по знаковым системам 20: 12-16.]

- 1988. Klio na rasput'e. Nashe nasledie 5: 1-4. [Клио на распутье. Наше наследие 5: 1-4.]

- 1990. Universe of the Mind: A Semiotic Theory of Culture. (Shukman, Ann, trans.; Eco, Umberto, intr.) London, New York: I. B. Tauris.

- 1992. Ot redkollegii. Trudy po znakovym sistemam [Sign Systems Studies] 25: 3-4. [От редколлегии. Труды по знаковым системам 25: 3-4.]

- 1993. Zimnie zametki o letnih shkolah. Novoe literaturnoe obozrenie 3: 40-42. [Зимние заметки о летних школах. Новое литературное обозрение 3: 40-42.]

- 1995. Ne-memuary. In: Permyakov, Evgenij (ed.), Lotmanovskij sbornik 1. Moscow: ITsGarant, 5-53. [Не-мемуары. In: Пермяков, Евгений (ред.), Лотмановский сборник 1. Москва: ИЦ-Гарант, 5-53.]

- 2005. On the semiosphere. (Clark, Wilma, trans.) Sign Systems Studies 33(1): 203-229.

- 2014. Non-Memoirs. (Brickman, Caroline Lemak, trans., annot.; Bershtein, Evgenij, ed.) Champaign, London, Dublin: Dalkey Archive Press.

- 2016[1982]. Universitet - nauka - kul'tura. In: Lotman, Juri M.; Uspenskij Boris A. Perepiska 1964-1993. (Kel'bert, Ol'ga; Trunin, Mikhail; Uspenskij, Boris, eds.) Tallinn: Tallinn University Press, 679-688. [Университет - наука - культура. In: Лотман Ю. М., Успенский Б. А. Переписка 1964-1993 (Кельберт, О. Я.; Трунин, М. В.; Успенский, Б. А., ред.) Таллинн: Издательство ТЛУ, 679-688.] 
Lotman, Juri; Uspenskij, Boris 1971. O semioticheskom mehanizme kul'tury. Trudy po znakovym sistemam [Sign Systems Studies] 5: 144-166. [Лотман, Ю. М.; Успенский, Б. А. 1971. О семиотическом механизме культуры. Труды по знаковым системам 5: 144166.]

- 1978. On the semiotic mechanism of culture. (Mihaychuk, George, trans.) New Literary History 9(2): 211-232.

- 2016. Perepiska 1964-1993. Kel'bert, Ol'ga; Trunin, Mikhail; Uspenskij, Boris (eds.) Tallinn: Tallinn University Press. [Лотман, Ю. М.; Успенский, Б. А. 2016. Переписка 1964-1993. Кельберт, О. Я.; Трунин, М. В.; Успенский, Б. А. (ред.) Таллинн: Издательство ТЛУ.]

Mints, Zara; Malevich, Oleg 1958. A. N. Tolstoj v Chehoslovakii v 1935 g. Trudy po russkoj i slavyanskoj filologii [The Studies on Russian and Slavic Philology] 1: 204-214. [Минц, 3. Г.; Малевич, О. М. 1958. А. Н. Толстой в Чехословакии в 1935 г. Трудь по русской и славянской филологии 1: 204-214.]

Pern, Tanel 2012. History as communication in the works of Tartu-Moscow School. In: Proceedings of the 10th World Congress of the International Association for Semiotic Studies (IASS/AIS). A Coruña: Universidade da Coruña, 453-458.

Pilshchikov, Igor; Trunin, Mikhail 2015. K sporam o ritmicheskoj prirode "Slova o polku Igoreve" (Neopublikovannyj otzyv J. M. Lotmana o stat'e L. I. Timofeeva i ego mesto v nauchnom kontekste 1960-1970-h godov). Russkaya literatura 1: 30-57. [Пильщиков, И. А.; Трунин, М. В. 2015. К спорам о ритмической природе «Слова о полку Игореве» (Неопубликованный отзыв Ю. М. Лотмана о статье Л. И. Тимофеева и его место в историко-научном контексте 1960-х - 1970-х годов). Русская литература 1: 30-57.]

Plyuhanova, Maria 1995. Issledovaniya J. M. Lotmana po drevnerusskoj literature i XVIII veku. In: Permyakov, Evgenij (ed.), Lotmanovskij sbornik 1. Moscow: ITs-Garant, 180-187. [Плюханова, М. Б. 1995. Исследования Ю. М. Лотмана по древнерусской литературе и XVIII веку. In: Пермяков, Евгений (ред.), Лотмановский сборник 1. Москва: ИЦГарант, 180-187.]

Seyffert, Peter 1985. Soviet Literary Structuralism: Background; Debate; Issues. Columbus, Ohio: Slavica.

Trunin, Mikhail 2016. “Ochen' ploho otnoshus' k etomu deyatelyu”: Lotman ob Eisensteine kak predshestvennike strukturalizma. Novoe literaturnoe obozrenie 139: 97-110. [Трунин, Михаил 2016. «Очень плохо отношусь к этому деятелю»: Лотман об Эйзенштейне как предшественнике структурализма. Новое литературное обозрение 139: 97-110.]

Uspenskij, Boris 1974. Historia sub specie semioticae. In: Lotman, Juri (ed.), Materialy vsesoyuznogo simpoziuma po vtorichnym modeliruyushchim sistemam I(5). Tartu: University of Tartu, 119-130. [Успенский, Б. А. 1974. Historia sub specie semioticae. In: Лотман, Ю. М. (ред.), Материаль Всесоюзного симпозиума по вторичным моделирующим системам I(5). Тарту: Тартуский государственный университет, 119-130.]

- 1976. Historia sub specie semioticae. In: Bazanov, Vasilij G. (ed.), Kul'turnoe nasledie Drevnej Rusi: Istoki. Stanovlenie. Traditsii. Moscow: Nauka, 286-292. [Historia sub specie semioticae. In: Базанов, В. Г. (ред.), Культурное наследие Древней Руси: Истоки. Становление. Традиции. Москва: Наука, 286-292.]

- 1987. K probleme genezisa tartusko-moskovskoj semioticheskoj shkoly. Trudy po znakovym sistemam [Sign Systems Studies] 20: 18-21. [К проблеме генезиса тартуско-московской семиотической школы. Труды по знаковым системам 20: 18-21.] 
- 1988. Istoriya i semiotika (Vospriyatie vremeni kak semioticheskaya problema). Stat'ya pervaya. Trudy po znakovym sistemam [Sign Systems Studies] 22: 66-84. [История и семиотика (Восприятие времени как семиотическая проблема). Статья первая. Труды по знаковым системам 22: 66-84.]

- 1989. Istoriya i semiotika (Vospriyatiye vremeni kak semioticheskaya problema). Stat'ya vtoraya. Trudy po znakovym sistemam [Sign Systems Studies] 23: 18-38. [История и семиотика (Восприятие времени как семиотическая проблема). Статья вторая. Труды по знаковым системам 23: 18-38.]

- 1991. Semiotik der Geschichte. Vienna: Verlag der Österreichischen Akademie der Wissenschaften.

- 1996. Izbrannye trudy. Vol. 1: Semiotika istorii; Semiotika kul'tury. Moscow: Yazyki russkoj kul'tury. [Избранные труды. T. 1: Семиотика истории; семиотика культуры. Москва: Языки русской культуры.]

- 2016. O Moskovsko-tartuskoj semioticheskoj shkole. In: Lotman, Juri M.; Uspenskij Boris A. Perepiska 1964-1993. (Kel’bert, Ol'ga; Trunin, Mikhail; Uspenskij, Boris, eds.) Tallinn: Tallinn University Press: 696-700. [О московско-тартуской семиотической школе. In: Лотман, Ю. М., Успенский, Б. А. Переписка 1964-1993 (Кельберт, О. Я.; Трунин, М. В.; Успенский, Б. А., ред.) Таллинн: Издательство ТЛУ, 696-700.]

Vernadskij, Vladimir I. 1965. Himicheskoe stroenie biosfery Zemli i ee okruzheniya. (Baranov, Vladimir I., ed.) Moscow: Nauka. [Вернадский, В. И. 1965. Химическое строение биосферы Земли и ее окружения. (Баранов, В. И., ред.) Москва: Наука.]

Zimin, Aleksandr 1971. O stat'e J. Lotmana “Ob oppozitsii chest' - slava v svetskih tekstah Kievskogo perioda”. Trudy po znakovym sistemam [Sign Systems Studies] 5: 464-468. [Зимин, А. А. 1971. О статье Ю. Лотмана «Об оппозиции честь - слава в светских текстах Киевского периода». Труды по знаковым системам 5: 464-468.]

Zolyan, Suren 2013. O nepredskazuemosti proshlogo: J. M. Lotman ob istorii i istorikah. In: Pilshchikov, Igor (ed.), Sluchajnost' i nepredskazuemost' v istorii kul'tury: Materialy Vtoryh Lotmanovskih dnej v Tallinnskom universitete. Tallinn: Tallinn University Press, 31-77. [Золян, Сурен 2013. О непредсказуемости прошлого: Ю. М. Лотман об истории и историках. In: Пильщиков, И. А. (ред.), Случайность и непредсказуемость в истории культурь: Материаль Вторых Лотмановских дней в Таллиннском университете. Таллинн: Издательство ТЛУ, 31-77.]

Żyłko, Bogusław 2011. Kultura i znaki: Semiotyka stosowana w szkole tartusko-moskiewskiej. Gdańsk: Wydawnictwo Uniwersytetu Gdańskiego.

\section{Семиосфера и история: к истокам семиотического подхода к истории}

В статье рассматриваются трактовки семиотики истории у двух ведущих представителей Тартуско-московской семиотической школы - Ю. М. Лотмана и Б. А. Успенского. Демонстрируется, что лотмановский вариант семиотики истории тесно связан с разработкой его теории семиосферы (в частности, указывается на то, что, несмотря на постоянный интерес Лотмана к исторической проблематике, теоретическое осмысление исторического процесса фактически явилось следствием размышлений ученого о семиосфере, а не предшествовало им), то есть переходом от конкретно-исторических 
исследований к типологическим. В то же время лингвист Успенский, начинавший как специалист по структурной типологии языков, двигался в противоположном направлении, все больше занимаясь конкретно-историческими исследованиями. На материале переписки Лотмана с Успенским показано, что полуформальное научное общение представителей тартуско-московской школы зачастую играло ведущую роль при рождении основополагающих идей и разработке теоретических концептов.

\section{Semiosfäär ja ajalugu: kust saab alguse semiootiline lähenemine ajaloole}

Artiklis kõrvutatakse kahe Tartu-Moskva koolkonna keskse kuju - Juri Lotmani ja Boriss Uspenski - lähenemist ajaloosemiootikale. Väidetakse, et Lotmani lähenemine ajaloosemiootikale on tihedalt seotud tema semiosfääriteooria väljatöötamisega (hoolimata Lotmani vaibumatust huvist ajaloo vastu jäi ajalooprotsessi teoreetiline tõlgendamine tema jaoks tegelikult semiosfääri üle mõtisklemise varju). S.t nihkega tema teadustöös ajalooliskirjanduslike üksikjuhtumite uurimiselt tüpoloogiatele. Samas liikus Uspenski, keeleteadlane, kes alustas strukturaalse keeletüpoloogia uurijana, vastassuunas, hakates üha enam tegelema ajalooliste üksikjuhtumite vaatlemisega. Lotmani kirjavahetus Uspenskiga on tõendiks, et uusi alustrajavaid ideid ning teoreetiliste mõistete edasiarendamist inspireeris sageli Tartu-Moskva koolkonna esindajate poolformaalne suhtlus teadusteemadel. 